\title{
$\beta$-catenin/Tcf-signaling appears to establish the murine ovarian surface epithelium (OSE) and remains active in selected postnatal OSE cells
}

\author{
Macalister Usongo ${ }^{1}$ and Riaz Farookhi ${ }^{1,2,3,4^{*}}$
}

\begin{abstract}
Background: Wnts are a family of secreted signaling molecules involved in a number of developmental processes including the establishment of cell fate, polarity and proliferation. Recent studies also implicate wnts in epithelial adult stem cell maintenance, renewal and differentiation. Wnts transduce their signal through one of three signaling pathways. The best studied, the wnt/ $\beta$-catenin pathway, leads to an increase in intracellular $\beta$-catenin which acts as a co-transcription factor with members of the Tcf/Lef family. A number of wnts are expressed in the ovary, specifically in the membrana granulosa and ovarian surface epithelium (OSE). We investigated the spatiotemporal pattern of $\beta$-catenin/Tcf expression in the OSE using responsive transgenic (TopGal) mice.

Results: The generated $\beta$-galactosidase response $\left(\operatorname{lac} Z^{+}\right)$identified the cell population that overlies the mediolateral surface of the indifferent gonad at embryonic day (E) 11.5. From E12.5 onwards, lacZ expression disappeared in cells covering the testis but remained with ovary development. LacZ ${ }^{+}$OSE cells were present throughout embryonic and postnatal ovarian development but demonstrated an age-dependent decrease to a small proportion when animals were weaned and remained th this proportion with aging. Flow cytometric (FACS) and ovarian section analyses showed lacZ $Z^{+}$cells constitute approximately $20 \%$ of OSE in postnatal (day 1) mice which fell to $8 \%$ in 5 day-old animals while in prepubertal and adult mice this accounted for only $0.2 \%$ of OSE. Apoptosis was undetected in OSE of neonates and $\beta$-catenin/Tcf-signaling cells were proliferative in neonatal mice indicating that neither cell death nor proliferation failure was responsible for the proportion alteration. It appeared that lac $Z^{+}$ cells give rise to lac $Z^{-}$cells and this was confirmed in cell cultures. The DNA-binding dye DyeCycle Violet was used to set up the side population (SP) assay aimed at identifying subpopulations of OSE cells with chemoresistance phenotype associated with ABCG2 transporter activity. FACS analysis revealed lac $Z^{+}$cells exhibit cytoprotective mechanisms as indicated by enrichment within the SP.
\end{abstract}

Conclusions: The study raises the possibility that wnt/ $\beta$-catenin-signaling cells constitute a progenitor cell population and could underlie the pronounced histopathology observed for human ovarian cancer.

Keywords: Ovarian surface epithelium, Wnts, $\beta$-catenin/Tcf-signaling, lacZ, Transgenic mice

\section{Background}

Wnts are secreted cysteine rich glycoprotein ligands that transduce their signal through at least three distinct pathways [1]. The wnt/ $\beta$-catenin pathway (termed canonical wnt-signaling) is the best studied and arises from an increase in non-phosphorylated intracellular $\beta$-catenin

\footnotetext{
* Correspondence: riaz.farookhi@mcgill.ca

'Departments of Experimental Medicine, McGill University, Montreal, QC, Canada

${ }^{2}$ Obstetrics and Gynecology, McGill University, Montreal, QC, Canada

Full list of author information is available at the end of the article
}

content, transport to the cell nucleus and association with members of the Tcf/Lef transcription factor family to drive target gene expression [2]. Wnts are involved in a number of developmental processes including the establishment of cell fate, proliferation, and differentiation [3-5]. In mice, Wnt4 is associated with female sexual differentiation [6] and is required during emergence of the female gonad to prevent formation of the male-specific coelomic blood vessel and steroidogenic cell migration $[7,8]$. In addition to $w n t 4$, sex-specific expression has been found for wnt5a, wnt6 and wnt $9 a$ within the gonad [9]. Recent findings also

\section{Biomed Central}


implicate a family of secreted ligands (R-spondin) in female sex-determination [10,11]. The R-spondins (Rspos) play an essential role in ovarian development through stabilization of cytoplasmic $\beta$-catenin. Mutation of Rspo 1 is associated with human sex reversal [10]. Expression of Rspo proteins overlaps with expression of whts during development indicating a link between Rspo and the wnt signaling pathway [12].

While wnts play a key role in embryonic development of the ovary $[6,13,14]$, several studies describe the expression of wnts and wnt signaling components in adult rodent ovaries [15-20]. Some of these, including wht4 [21] and $w n t 2 b$ [22], are associated with activation of canonical wnt signaling. Interestingly, $w n t 2 b$ is expressed in the ovarian surface epithelium (OSE) [18]. OSE is a simple epithelium of squamous or cuboidal cells and it, as well as Mullerian duct derivatives (oviduct, uterus, and proximal one-third of vagina), are derived from the peritoneal mesothelium [23,24]. Functionally, OSE is implicated in the ovulatory process and is responsible for repair of the ovulatory wound [25,26]. Deregulation of wnt-signaling in OSE has been implicated in ovarian tumorigenesis [27].

The spatio-temporal pattern of $\beta$-catenin/Tcf-signaling activity within murine OSE (mOSE) was investigated using a specific transgenic reporter mice (TopGal) strain [28]. We show that $\beta$-catenin/Tcf activation identifies a cell population in the mesothelium that overlies the indifferent gonad. By embryonic day (E) 12.5, the majority of cells in the overlying epithelium of the ovary retain $\beta$ -
catenin/Tcf-signaling cells while they disappear in cells covering the testis. At parturition the proportion of signaling to non-signaling mOSE cells decrease and fall to a small but sustained proportion in adult females. The $\beta$-catenin/Tcf-signaling population in adult females is enriched for a side population which is believed to be a characteristic of stem cells [29]. These observations might explain why ovarian cancers show oviduct/uterine histopathology as OSE share an origin with Mullerian duct derived reproductive tissues [30].

\section{Results}

$\beta$-catenin/tcf-activated lacZ expression is seen on cells covering the indifferent mouse gonad

Prominent lac $\mathrm{Z}^{+}$stained cells overlie the entire mediolateral surface of the indifferent gonad on embryonic day 11.5 (E11.5; Figure 1A). Coelomic epithelial cells extending beyond the genital ridge towards either the rostral or caudal end of the mesonephros (Figure 1A, arrowhead), did not stain indicating that only the mesothelium directly covering the gonad has $\beta$-catenin/Tcf-mediated signaling. To identify the cell types in which $\beta$-catenin /Tcf-signaling was activated, paraffin-embedded sections of E11.5 gonads were examined. Somatic (surface and sub-surface) as well as Mullerian duct cells of E11.5 gonads showed lacZ expression (Figure 1B; dark arrows and arrow head, respectively); germ cells, distinguished by their large round nuclei, were not stained (Figure 1B, white arrowheads).
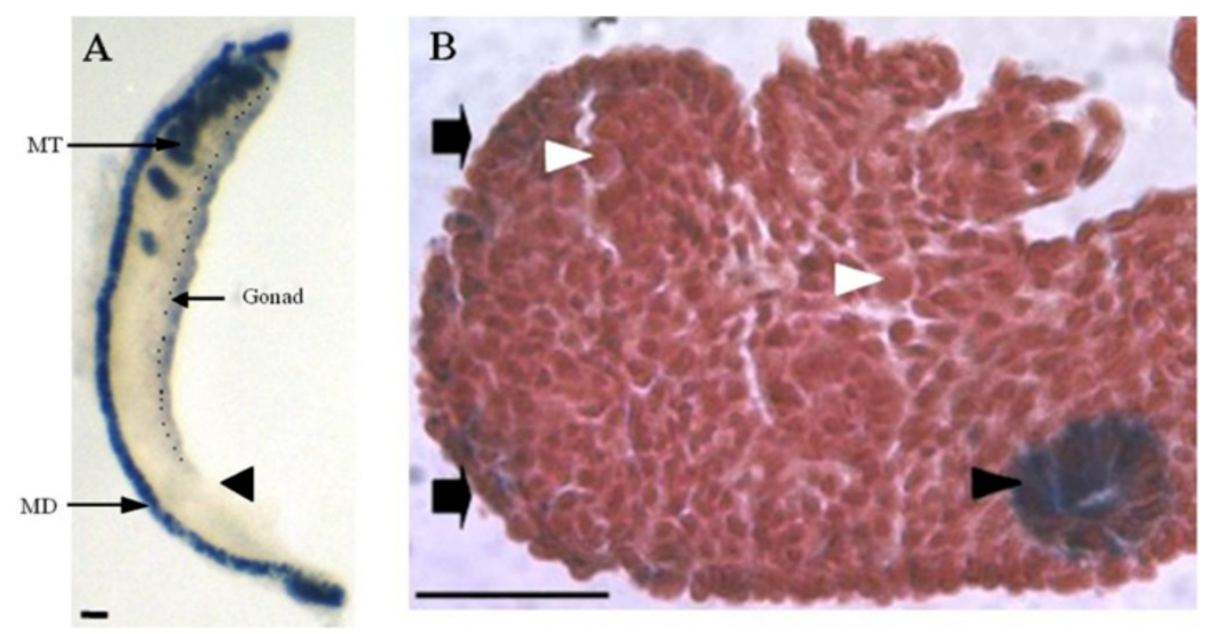

Figure 1 Coelomic epithelium overlying the indifferent gonad displays $B$-catenin/Tcf-mediated lacZ expression. Panel A: Whole-mount Xgal staining of E11.5 urogenital ridge. LacZ positive cells overlie the medio-lateral surface of the indifferent gonad (dotted line demarcates the gonad). The mesonephric duct (MD) and mesonephric tubules (MT) also stain for lacZ. Arrowhead indicates coelomic epithelium extending beyond the gonad is not stained. Scale bar $=10 \mu \mathrm{m}$. Panel B: Section of an X-gal stained E11.5 urogenital ridge. LacZ staining is present in the gonadal surface epithelium (arrows), cells beneath the surface and the mesonephric ducts (black arrow head). Germ cells (white arrow head) do not stain for lacZ. Scale bar $=50 \mu \mathrm{m}$. 


\section{$\beta$-catenin/tcf-mediated lacZ expression shows sexual} dimorphism in the cells covering the developing gonad Gonadal $\beta$-catenin/Tcf-mediated lacZ-expression was examined at later stages of embryonic development. Sexual dimorphic patterns of lacZ staining were observed at E12.5 (Figure 2, upper and lower left panels). In E12.5 females, pronounced staining was observed over the entire gonadal surface while E12.5 males displayed less extensive staining compared to either the E11.5 indifferent gonad (Figure 1A) or the E12.5 ovary (Figure 2, upper left panel).

The ovarian surface at E13.5 maintained extensive lacZ expression with a bias towards the cranial pole (Figure 2, black arrows). In contrast, staining in the E13.5 testis had almost disappeared with some staining retention at the caudal pole (Figure 2, arrowhead). Staining in E14.5 ovaries was similar to that at E13.5 with an anterior bias towards the cranial suspensory ligament. E14.5 testes were devoid of lac $\mathrm{Z}^{+}$cells except for the region near the mesonephric tubules and faint staining at the caudal pole. In E15.5 ovaries, lacZ staining remained prominent while testes were devoid of lacZ ${ }^{+}$cells with the exception of the mesonephric tubule attachment (right panels, Figure 2). In both sexes, lacZ staining was present in Wolffian (WD) and Mullerian (MD) ducts as well as mesonephric tubules (MT). The sex-specific degeneration of the MD in the male by E15.5 (Figure 2, lower right panel) is apparent with retention of WD. The female (Figure 2 upper right panel) loses her WD at a later age, generally at E16-5 - E17.5 (not shown).

The disappearance of $\beta$-catenin/Tcf-mediated lacZ expression on the surface of developing testes raised the possibility of cell loss and coverage with a tough capsule i.e. establishment of the testicular tunica albuginea. In order to assess this possibility, basement membranes were highlighted by Periodic acid-Schiff (PAS) staining of lacZ-stained E15.5 gonad sections. A thin basement
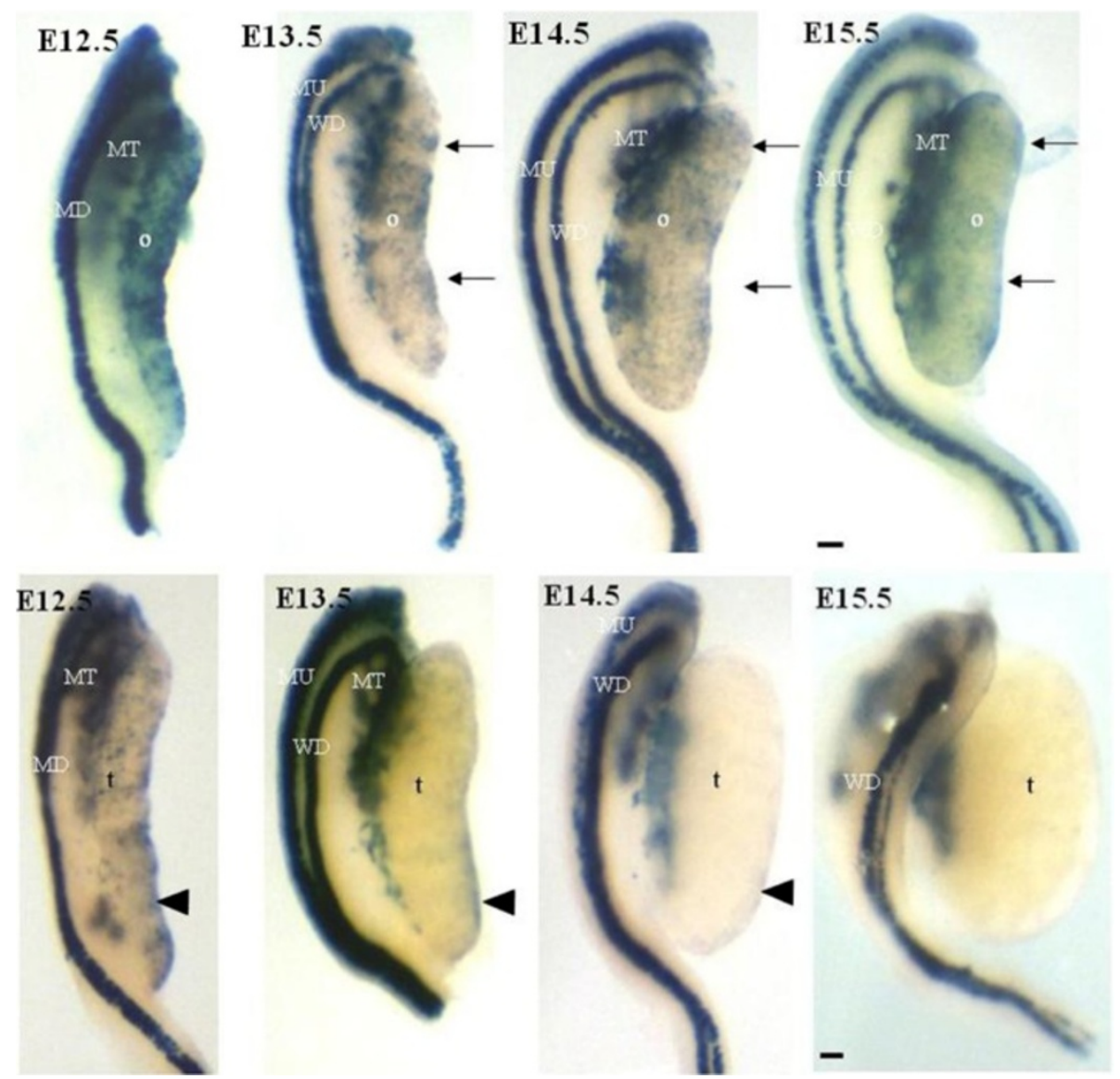

Figure 2 ß-catenin/Tcf-mediated lacZ expression is maintained in the embryonic female gonad. Time course of $B$-catenin/Tcf-mediated transcription in female (upper panels) and male (lower panels) embryonic gonads. Whole-mount X-gal staining demonstrates B-catenin/Tcf expression is sexually dimorphic from E12.5 onwards. Blue (lacZ) staining reflecting B-catenin/Tcf-mediated transcription is observed in the mesonephric tubules (MT), mesonephric duct (MD), Mullerian duct (MU), Wolffian duct (WD), ovaries (o) and testis (t). Black arrows indicate the anterior region of the female gonad. Arrowhead indicates the ventral surface and posterior tip of the male gonad. All gonads are positioned with the anterior region at the top of each panel. Scale bar $=10 \mu \mathrm{m}$. 
membrane (arrow; Figure 3 left panel) was observed below OSE and the lac $Z^{+}$and lac $Z^{-}$epithelial cells (arrowhead; Figure 3 left panel). Germ and pregranulosa cells, organized into structures termed ovigerous cords in developing ovaries [31], were delimited by a thin basement membrane. Gonadal surface cells of E15.5 testis did not stain for lacZ expression and appeared more elongated than E15.5 OSE cells (arrowhead; Figure 3 right panel). A basement membrane was observed underneath and between the epithelial cells of E15.5 testis and appeared to thicken at this stage (arrow; Figure 3 right panel). Testis cords consisting of germ and Sertoli cells [32] were surrounded by a basement membrane. These observations indicate that the testicular loss of $\beta$-catenin/Tcf-mediated lac $Z$ expression is not due to surface cell elimination.

\section{$\beta$-catenin/tcf-mediated lacZ expression in mOSE is heterogeneous during postnatal development}

Whole-mount lacZ staining of ovaries derived from postnatal mice (P1-P180) revealed staining and demonstrated an age-dependent decrease in the relative proportion of stained cells (Figure 4a). Histological examination of sections derived from P1 to P21 mice showed staining in the OSE (Figure $4 \mathrm{~b}$ ) and an age-dependent decrease in lac $\mathrm{Z}^{+}$ OSE cells. No distribution pattern for lac $Z^{+}$cells within the OSE was detected at these ages.

In order to quantify changes in the proportion of lac $\mathrm{Z}^{+}$to total OSE with animal age, cells were isolated from the ovarian surface using an enzymatic procedure and analyzed by flow cytometry. This approach was tested to ensure that OSE cells only were released. Ovary-encompassing OSE was selectively labeled using the water-soluble reagent NHS-biotin. Exposure of an intact ovary to the reagent for a brief time interval followed by quenching with excess glycine provides specific OSE labeling. Tight junctions between OSE cells and the presence of a basement membrane prevent the reagent from entering into the ovarian parenchyma [33]. Indeed, OSE cells are labeled specifically with NHS-biotin with minimal penetration into the parenchyma as visualized by the binding of FITCconjugated avidin to NHS-biotin stained P21 ovary (Arrow head; Figure 5a panel A).

The efficiency of OSE isolation was assessed after subjecting NHS-biotin labeled ovaries to enzymatic treatment. The majority ( $>90 \%$ ) of the labeled cells were removed and the residual ovary remained relatively intact (Figure 5a panel B). FACS analysis of the isolated cells showed that approximately $86 \pm 2.3 \%$ (mean \pm sem; $n=3$ ) of the cells were labeled with avidin-FITC (Figure 5b) after enzyme treatment. The proportion of viable cells, assessed by concurrent analysis of cell viability (7-AAD labeling), corresponded with those of unlabeled OSE from control ovaries.

After sorting NHS-biotin-labeled cells through FACS, cytokeratin 8 (CK8) detection with Cy3-labeled goat anti-mouse antibody was conducted (Figure 5c). Ovarian section from P21 mice was used as a control for the specificity of CK8 antibody to OSE cells (Figure 5d).

Figure $6 \mathrm{a}$ illustrates the percentage of lacZ-positive mOSE cells as a function of animal age. The proportion of lac $\mathrm{Z}^{+}$cells within OSE decreased from approximately $8 \%$ at $\mathrm{P} 5$ to $0.2 \%$ by $\mathrm{P} 21$ and it remained at this level with continued aging (Figure 6a). FACS results were confirmed by counting lacZ-positive and negative cells in serial sections of P1, P5, and P10 ovaries (Figure 6b). The percentage of lacZ-positive OSE cells at P5 and P10 by serial counting was similar to the same measurement through FACS analysis at these ages. Sections from older animals were difficult to evaluate owing to the relative rarity of lacZ-positive OSE cells and the larger number of sections generated.

Since the proportion of OSE cells expressing lacZ decreased with age, it is possible that $\beta$-catenin/Tcf expression drives cellular apoptosis. Accumulating evidence

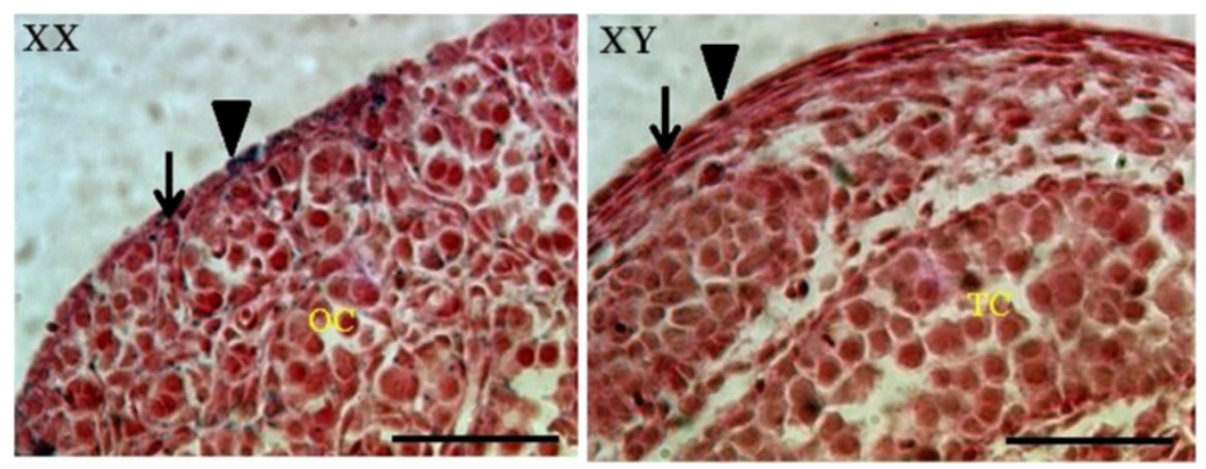

Figure 3 Loss of $ß$-catenin/Tcf-mediated lacZ expression in the testis is not due to gonadal surface cell elimination. E15.5 ovary (XX; left panel) and testis (XY; right panel) after Periodic acid-Schiff staining. The basement membrane (arrow) is deposited underneath the epithelial layer (arrow head) of gonads and surrounds ovigerous cords (OC) in XX and testis cords (TC) in XY gonads. Scale bar $=50 \mu m$. 


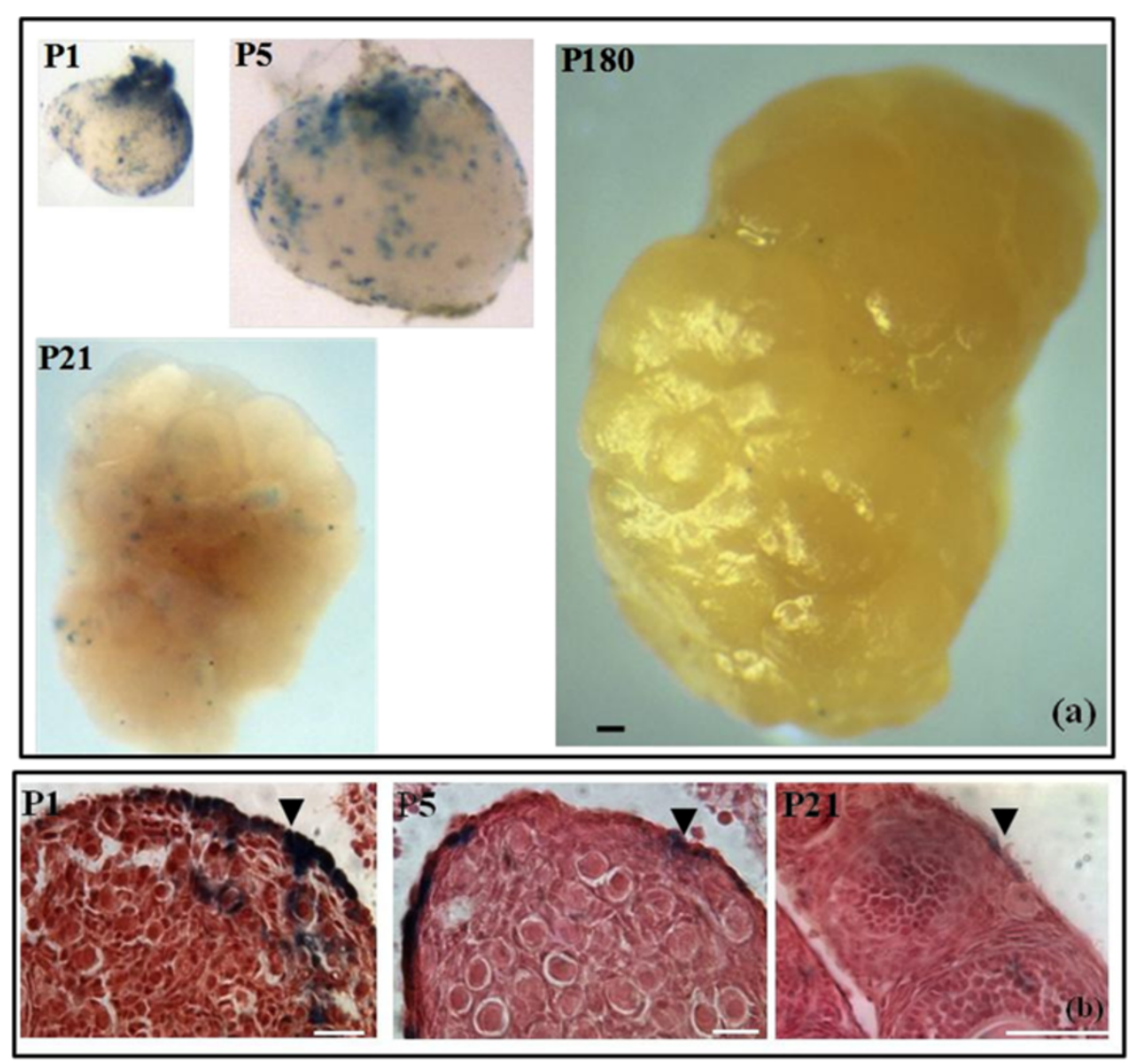

Figure 4 Heterogeneity of ß-catenin/Tcf-mediated lacZ expression in the ovarian surface epithelium (OSE). (a) B-catenin/Tcf-mediated lacZ expression during ovary development from postnatal day 1 (P1) to P180 indicating an age-dependent decrease in the proportion of stained cells. Scale bar $=100 \mu \mathrm{m}$. (b) X-gal staining of OSE cells during postnatal development from P1 to P21. LacZ ${ }^{+}$cells are present within the OSE (arrow heads) and indicate an age-dependent decrease in the proportion of stained OSE cells. Scale bar $=50 \mu \mathrm{m}$.

suggests that $\beta$-catenin is involved in cell cycle arrest [34] and apoptosis [35]. To investigate this possibility, the occurrence of apoptosis in P1 and P5 ovaries was analyzed by TUNEL. The positive control (DNase-treated ovary section) displayed staining in all cells (Figure 7, bottom panel). There was no evidence of DNA fragmentation in P1 and P5 ovaries (Figure 7, top and middle panel), suggesting absence of apoptosis even though significant changes in the proportion of lac $Z^{+}$cells were seen at these ages (Figure 6).

It was possible that the age-dependent decrease in the proportion of lac $\mathrm{Z}^{+}$cells arose because they were nonreplicating. Cell proliferation was assessed immunohistochemically after incorporation of the thymidine analog, bromodeoxyuridine (BrdU), into cellular DNA. To enumerate proliferating lac $\mathrm{Z}^{+}$cells, ovaries were collected $48 \mathrm{hr}$ post $\mathrm{BrdU}$ injection and stained for lacZ and BrdU (Figure 8). At P4, approximately $25 \%$ of lac $Z^{+}$cells are BrdU-labeled but by $\mathrm{P} 9$ this falls to $8 \%$ (Table 1 ). This indicates lac $\mathrm{Z}^{+}$cell replication decreases with age. The observation that there is an age-dependent decrease in the number and rate of replication of lac $\mathrm{Z}^{+}$cells raises the possibility that proliferating lac $Z^{+}$cells give rise to non-signaling cells. To assess this possibility, OSE cells from P5-P9 were harvested and cultured. In four days, a 2-fold increase in lacZ $Z^{+}$cells and a three-fold increase in the number of lac $Z^{-}$cells were obtained (Figure 9). There was, however, no significant difference in proliferation rate between lac $\mathrm{Z}^{+}$and lac $\mathrm{Z}^{-}$cells. Prolonged culture for 8 days led to a significant decrease in lacZ $^{+}$cells whereas the number of lacZ cells increased. The latter observation suggests non-signaling cells arose from the previously signaling ones. To further confirm that lac $Z^{-}$arose from their positive counterparts, lac $Z^{+}$cells were sorted from lac $Z^{-}$cells and cultured separately. After 8 -days of culture, the majority of lac $Z^{+}$cells did not stain for lacZ (data not shown). LacZ cells, however, did not stain for lacZ following prolonged culture.

Wnt and fzd expression in OSE were unchanged with age Table 2 is a summary of $W n t$ and $f z d$ transcripts assessed for animals of different ages. Interestingly, with the exception of $f z d 6$ these particular wnts and $f z d s$ were either 


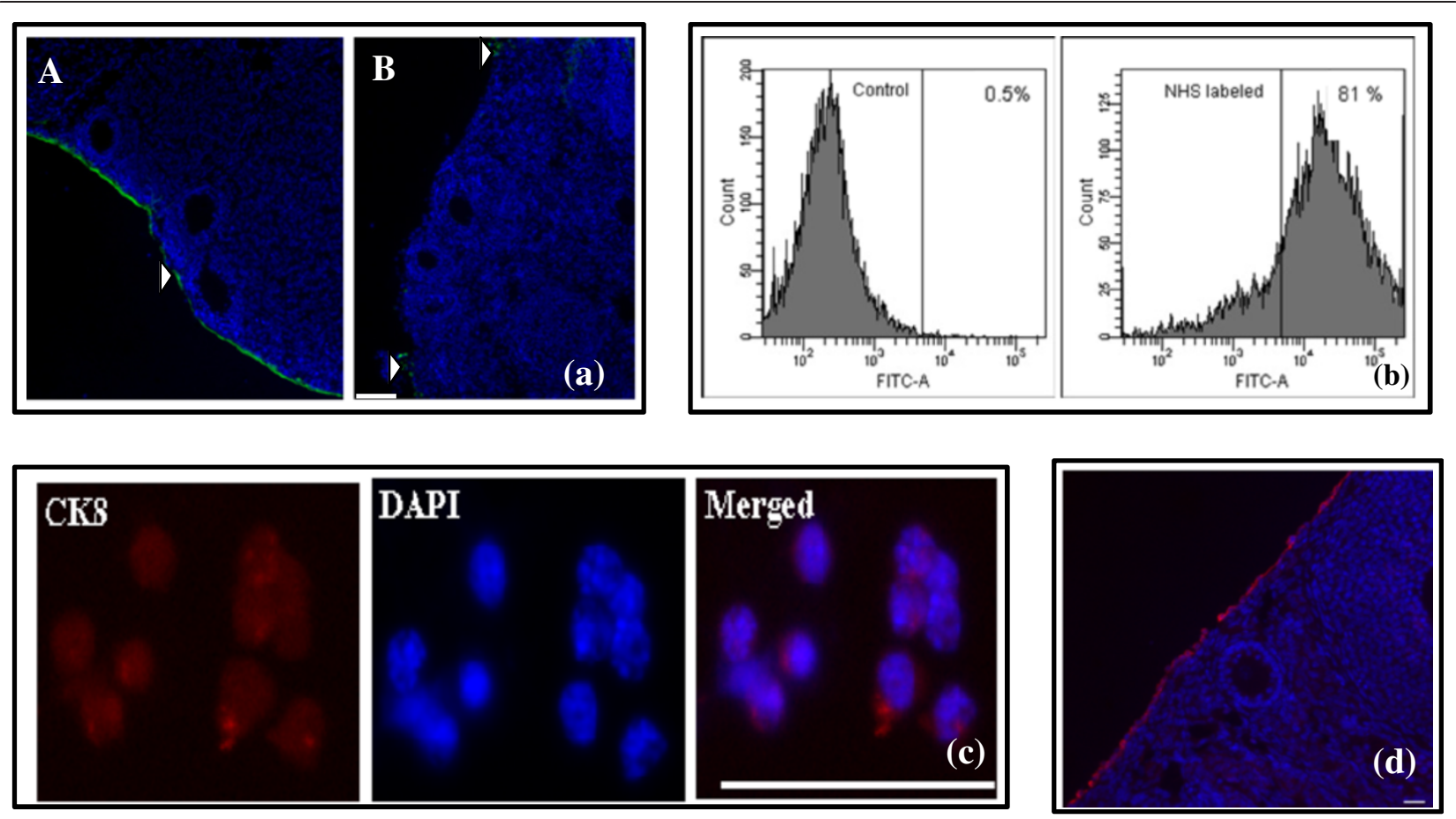

Figure 5 NHS-biotin labels OSE cells. (a) Panel A: A representative P21 NHS-biotin-labeled ovary section stained with avidin FITC (green) and counterstained with Hoechst 33342 (blue). NHS-biotin labels OSE cells with little penetrance of the reagent into ovarian parenchyma. Panel B: Collagenase/DNase I treatment results in isolation of a significant proportion of the OSE leaving remainder of the ovary relatively intact. Dotted line demarcates the OSE location. Arrowheads indicate labeled OSE cells. Scale bar = $100 \mu m$. (b) FACS analysis of non-NHS labeled (PBS) and NHS-biotin-labeled P21 OSE cells stained with avidin-FITC. Histogram showing that the majority of the cells stained for avidin-FITC indicating that they retained the NHS-biotin label following enzymatic treatment. A minimum of 10,000 cells were analyzed. (c) Cytokeratin 8 (CK8) staining of OSE cells. OSE cells were isolated following enzymatic digestion of NHS-biotin labeled ovary in collagenase/DNase I in DMEM. Released cells were stained with avidin-FITC and FITC-positive cells sorted, stained for CK8 (red) and counterstained with DAPI (blue). Scale bar = 50 $\mu$ m. (d) CK8 staining of P21 ovary. Immunostaining for CK8 labels OSE specifically (red). Scale bar= $50 \mu \mathrm{m}$.

expressed or not expressed regardless of animal age. The cause for non-expression of $f z d 6$ in adult mice is not known nor which particular wnt signals through this receptor. Fzd6 is an essential component of the hair patterning pathway [36] and mutation of $f z d 6$ is known to cause autosomal-recessive nail dysplasia [37]. Since the proportion of lac $\mathrm{Z}^{+}$OSE cells in weaned (P21) and adult mice are similar, it is unlikely that the loss of $f z d 6$ transcription is affecting this aspect of wnt-signaling in OSE cells.

\section{$\mathrm{LacZ}^{+}$OSE cells are enriched with a potential stem cell population}

The observation that there is an age-dependent decrease to relative constancy of $\beta$-catenin/Tcf-signaling OSE cells prompted an examination of whether these cells exhibit a stem cell characteristic termed side population (SP). SP is detected by dual wavelength flow cytometry of the cellular efflux of the DNA-binding dyes Hoechst 33342 or dyecycle violet (DCV). SP cells appeared as a characteristic tail in the flow cytometry of isolated OSE (Figure 10). The SP cells were small round cells of approximately six $\mu \mathrm{m}$ in diameter (Figure 11). The dependence of the SP phenotype on expression of ABCG2 transporter pump was demonstrated by pre-incubation with the ABCG2 inhibitor verapamil. The results indicate that while $\sim 0.6 \%$ OSE of prepubertal mice is SP (Table 3), 23.9 $\pm 2 \%$ (mean $\pm \mathrm{SE}$, $\mathrm{n}=3$ ) of lacZ-positive cells are SP positive. This also indicates that the lac $\mathrm{Z}^{+}$cell population is heterogeneous with potential stem and non-stem cell components.

\section{Discussion}

Transgenic reporter (TopGal) mice indicate activation of $\beta$-catenin/Tcf signaling within OSE. This dominates the epithelium covering the indifferent gonad and is followed by its maintenance in a sex-specific manner. The majority, most likely all of the cells overlying the differentiating ovary, retain $\beta$-catenin/Tcf activity, which begins to disappear with testis formation. Further ovarian development shows an age-dependent decrease in the proportion of $\beta$-catenin/Tcf-responsive cells to relative constancy in the mature ovary. RT-PCR analysis detected the expression of multiple wnts and fzds within the OSE. Side population analysis indicates enrichment in $\beta$-catenin/Tcf-signaling cells. These findings suggest 

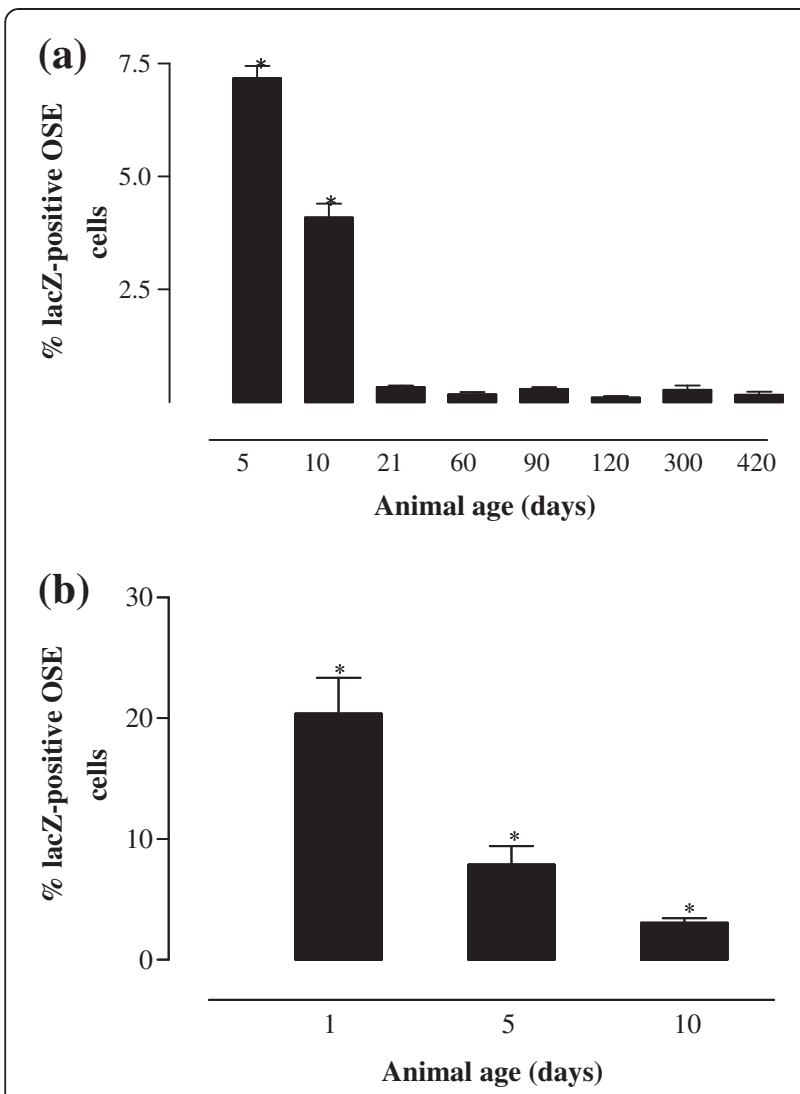

Figure 6 Age-dependent decrease in B-catenin/Tcf-signaling OSE cells. (a) The percentage of lacZ-positive OSE cells as a function of animal age estimated by FACS analysis. Error bars represent one SD from the mean and at least three replicates were used. *, denotes $P \leq 0.05$ between group means. A minimum of 10,000 cells were analyzed. (b) Serial count analysis of percentage of laczpositive OSE cells as a function of age. The percentage of lacZpositive OSE cells at P5 and P10 is quite similar to that obtained at these ages using FACS. Error bars represent one SD from the mean and at least three ovaries were counted. ${ }^{*}$, denotes $P \leq 0.05$ between means.

that $\beta$-catenin/Tcf signaling cells form the definitive OSE and raise the possibility that these signaling cells constitute a putative stem cell population.

$\beta$-catenin/Tcf-signaling plays critical role in embryonic patterning and cell fate determination in a variety of tissues [38]. Wilms' tumor suppressor 1 [39] and emptyspiracles homeobox gene 2 [40] expressed within the thickening coelomic epithelium of the developing gonad are required for genital ridge development. The presence of a lac $\mathrm{Z}^{+}$cell population overlying the $\mathrm{E} 11.5$ gonad suggests that the mouse gonad may be formed from a $\beta$ catenin/Tcf-signaling cell population. Coelomic epithelial cells migrate into $\mathrm{XX}$ and $\mathrm{XY}$ gonad and contribute to supporting cell lineage of the gonad [32]. The localization of lacZ ${ }^{+}$cells within E11.5 gonads raises the possibility that $\beta$-catenin/Tcf-mediated expression may be involved in differentiation of somatic cells of the developing gonad.

$\beta$-catenin is dispensable for testis formation and maintenance whereas it is required for maintenance of ovarian characteristics [41]. Several genes known to play a role in sexual development are transcribed in a sexually dimorphic fashion $[42,43]$. We observed sexual dimorphic $\beta$-catenin/Tcf-mediated expression that is distinct by E12.5. It is established that the presence of germ cells in female gonads is required for proper development of the ovary [44] and that sexual differentiation and meiotic entry of germ cells in embryonic XX gonads progress in an anterior-to-posterior pattern [45]. Our analysis demonstrated that lacZ expression in ovaries show the opposite wave pattern: an anterior bias observed by E13.5 and extends to the early postnatal period. This staining pattern wave is similar in its spatial distribution to that of Adamts19 a marker of ovarian somatic differentiation $[45,46]$ and raises the possibility that OSE differentiation begins posteriorly and moves anteriorly. This pattern of $\beta$-catenin/Tcf-mediated expression in the XX gonad may be due to a gradient of meiosis promoting substances produced by a fixed source in or near the anterior portion of the ovary. There is some evidence that the ovary in germ cell deficient mice is covered by OSE cells [47]. Thus, the observed ovarian lacZ expression pattern is unlikely due to a substance produced by germ cells but could be reflective of local environmental cues that are present in the embryonic female gonad.

Sry expression blocks $\beta$-catenin-mediated transcription [48]. The observation that loss of lacZ expression begins at the anterior portion of the developing testis mimicking Sry expression suggests that the anterior-posterior loss of lacZ on the surface of embryonic testis may be due to Sry expression. Because Sry is not expressed in the coelomic epithelium of a differentiating testis [49], it is unlikely that the loss of lacZ is due to Sry expression. Alternatively, non-cell autonomous paracrine signals such as Sox9, Mis, and Dhh emanating from Sertoli cells [50] may be responsible for blocking $\beta$-catenin/Tcf expression. It is possible that active steroidogenesis present in embryonic testis but absent in fetal ovary [51] may be preventing the $\beta$-catenin/Tcf-pathway from being efficiently expressed in the developing testis.

Several methods have been described for isolating OSE cells [52-55]. We have established a simple procedure for isolating a relatively pure population of OSE cells. This procedure owes its success to the fact that the NHS-biotin label is retained following enzymatic digestion. Additionally, biotinylation did not affect OSE cell viability. Sorted NHS-labeled cells stained for CK8 indicating that they were derived from the OSE. 


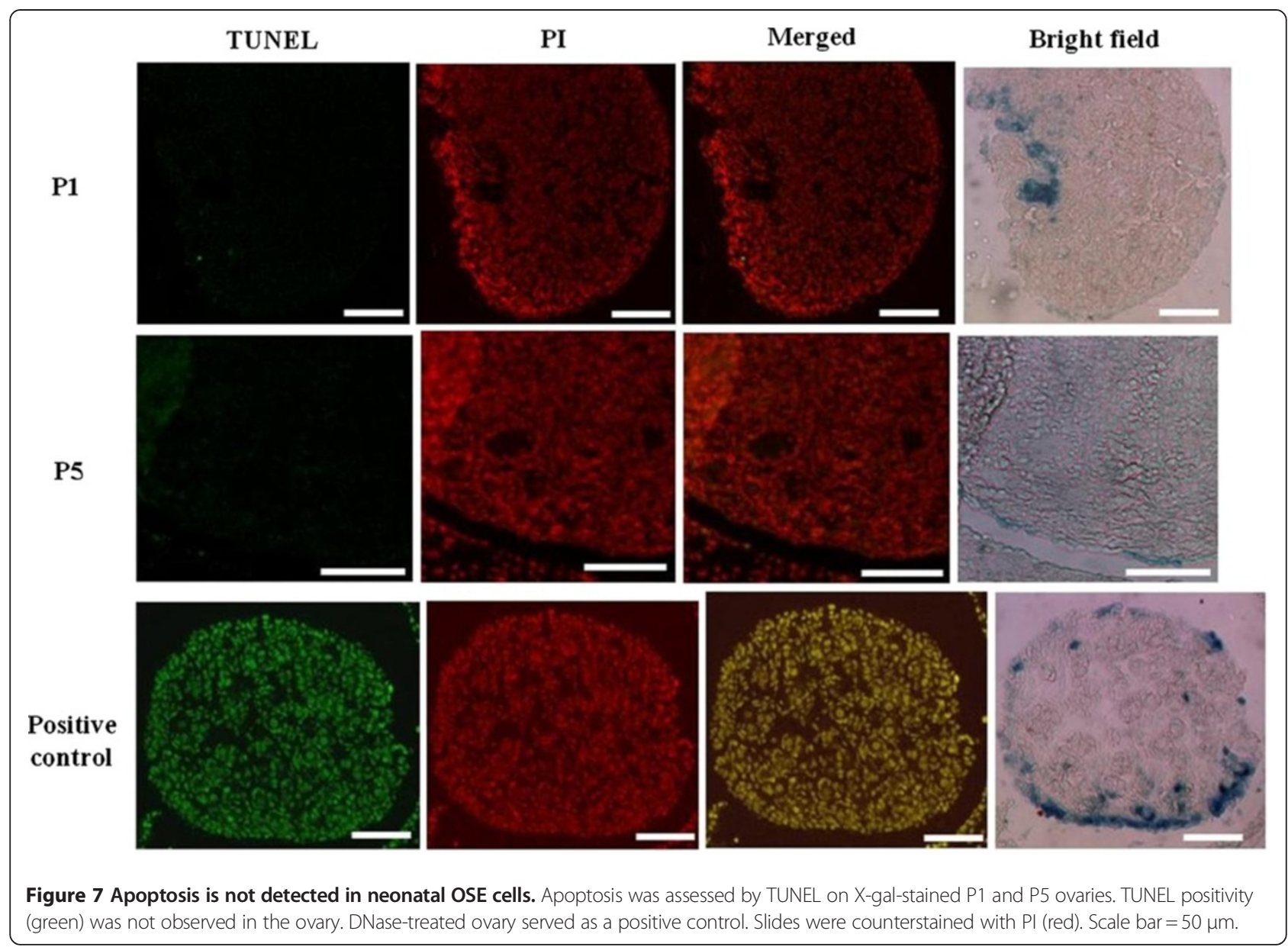

Some studies support a positive role of $\beta$-catenin in cell mitosis [56], whereas others suggest a potential involvement in cell cycle arrest [34] or a direct involvement in apoptosis [35]. $\beta$-catenin accumulation within the cell nucleus is however involved in cell fate decision [57]. We have shown that age-dependent decrease in $\beta$ catenin/Tcf-signaling cells is not due to the absence of cell proliferation or the result of selective apoptosis. Similar studies in day- 2 and day- 4 neonatal mouse ovaries reported the absence of apoptosis in all ovarian cell types [58]. We suspect that lacZ ${ }^{+}$cells were quiescent with continued aging and prepared for differentiation. It is likely that upon mitosis, a lacZ $Z^{+}$cell looses its ability to signal through the $\beta$-catenin/Tcf pathway and becomes non-signaling. This was reflected by the loss in proliferative capacity of lac $\mathrm{Z}^{+}$cells from $\mathrm{P} 4$ to $\mathrm{P} 9$. In vitro, lac $Z^{+}$cells showed a transient increase in cell number followed by appearance of lac $Z^{-}$cells suggesting that loss of lac $Z$ expression is due to cellular differentiation. The transient increase in lac $Z^{+}$cells may originate from symmetric division of lac $Z^{+}$cells or insufficient downregulation of $\beta$-catenin/Tcf-lacZ expression in vitro following mitosis. The observation that sorted lac $\mathrm{Z}^{+}$cells cultured separately from their non-signaling counterparts gave rise to lac $Z^{-}$cells provides the supporting evidence that loss of lacZ expression is due to OSE differentiation.

Knockout studies of various wnt molecules led to the discovery that wnts perform critical functions during early development of reproductive tissues [6,59]. Our studies show expression of various wnt ligands and fzd receptors transcripts within OSE. These are similar to previous studies assessing wnt/fzd expression within the ovary $[15,19]$. Among the wnts found to be expressed in the OSE are wnt-4 and wnt-2, which have been shown to impact ovary development $[6,60]$. The overlapping expression of multiple wnts within the OSE is suggestive of functional redundancy.

Gene expression analysis supports the hypothesis that human OSE cells are multipotent [61]. This hypothesis has recently been validated by a study that described putative stem cells within the OSE as cells expressing markers of pluripotency [62]. A side population-enriched and label-retaining cell population in the coelomic epithelium of adult mouse ovary has been identified as possible stem/ progenitor cells [26]. We obtained a distinguishable SP 

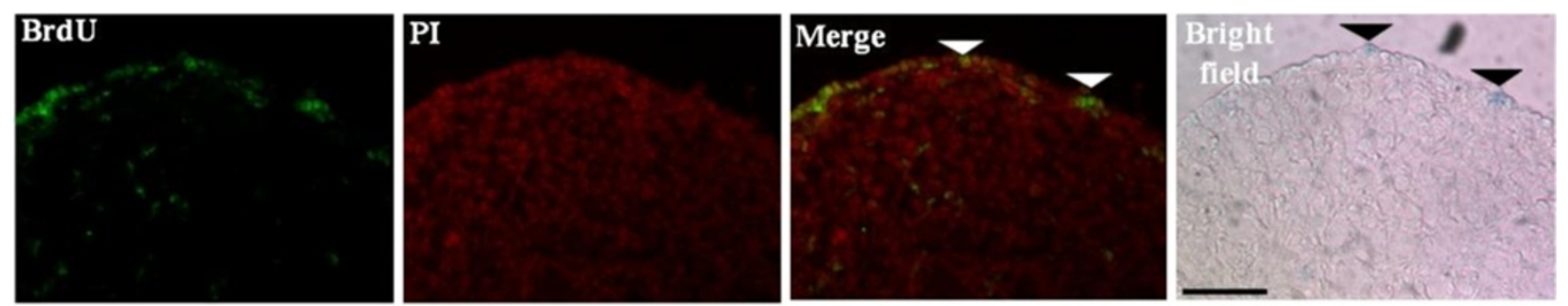

Figure 8 LacZ $^{+}$and lacZ $Z^{-}$neonatal OSE cells are proliferative. P2 mice were injected with BrdU 48 h prior to analysis. Ovaries were collected, X-gal stained, probed with anti-BrdU antibody (green) and counterstained with PI (red) to label cell nuclei. BrdU-positive cells were observed within somatic cells of the ovary (left panel) suggesting that mitosis is not restricted to the OSE. White arrow heads show BrdU ${ }^{+}$and black arrow heads lac $Z^{+}$cells. Scale bar $=50 \mu \mathrm{m}$.

within mouse OSE. The observation that the SP is enriched for $\beta$-catenin/Tcf-signaling cells raises the possibility that lacZ-positive cells constitute OSE progenitors. The fact that cancer stem cells are a subset defined by increased wnt/ $\beta$-catenin activity [63] and that wnt $/ \beta$-catenin is essential for maintenance of intestinal stem cells [64] supports our hypothesis. There is accumulating evidence suggesting that somatic stem cells may undergo mutagenic transformation into cancer stem cells [65]. Because many of the properties that define somatic stem cells also define cancer stem cells, our identification of a $\beta$-catenin/Tcf-signaling cell population in OSE raises the possibility that endometrioid adenocarcinomas may arise as a result of transformation of the lac $Z^{+}$cells. The common origin of the $\beta$-catenin/Tcf-signaling cells with oviduct/uterus may explain the suggestion that OSE cancers show uterine/oviductal characteristics [30].

\section{Conclusion}

Our findings indicate that $\beta$-catenin/Tcf-signaling cells are present early in OSE development. The maintenance of a constant number of $\beta$-catenin/Tcf-signaling cells accompanied by the increase in appearance of nonsignaling cells raises the possibility that the original $\beta$ catenin/Tcf-signaling cells give rise to a replacement as well as an expanding population of non-signaling progeny. Taken together, our results indicate that the mouse OSE is heterogeneous and may contain a population of progenitor cells. The physiological necessity for restoring OSE after ovulations may reflect the need for establishing and maintaining the progenitor cells. It also raises

Table 1 Proliferating lac $Z^{+}$cells as fraction of total lac $Z^{+}$ OSE cells. Data are presented as mean \pm standard error of the mean $(n=3)$

\begin{tabular}{cc}
\hline Animal age (days) & LacZ $^{+}$BrdU/LacZ $^{+}$ \\
\hline 4 & $23.6 \pm 1.67$ \\
9 & $8.0 \pm 0.48$ \\
\hline
\end{tabular}

the possibility, specifically in primates, that transformation of OSE progenitor cells can generate the varied histopathology observed in ovarian cancer.

\section{Methods}

\section{Reagents and chemicals}

Deoxyribonuclease I, collagenase (Type IV), and 5bromo-2'-deoxyuridine (Brdu) were purchased from Sigma Aldrich (St Louis, MO). Glycine, N, N-dimethyl formamide, and other general chemicals were of tissue culture grade and purchased from Fisher Scientific (Nepean, ON). Dulbecco's Modified Eagle Medium (DMEM), Minimum Essential Medium (MEM) alpha, 5bromo-4-chloro-3-indolyl- $\beta$-D-galactopyranoside (X-gal), dithiothreitol (DTT), propidium iodide (PI), 4', 6diamidino-2-phenylindole (DAPI), 7-aminoactinomycin D (7-AAD), and 5-chloromethylfluorescein di-b-D-galactopyranoside (CMFDG) kit were purchased from Invitrogen (Burlington, ON). Bovine serum albumin (BSA) and fetal bovine serum (FBS) were purchased from Wisent (StBruno, QC), Hoechst 33342 was purchased from Roche (Laval, QC), Tween-20 from Bio Basic Inc (Markham, ON), mowiol from Calbiochem (La Jolla, CA), and N-Hydroxysulfosuccinimide (Sulfo-NHS)-biotin from Pierce Thermo Fisher (Nepean, ON). Strepavidin phycoerythrin-Cy5 (PECy5) was obtained from Biolegend (San Diego, CA). The mouse monoclonal antibodies against cytokeratin-8 (TROMA-1) and BrdU (G3G4) were obtained from Developmental Studies Hybridoma Bank (DSHB; Iowa City, IA), Cy3-labeled goat anti-mouse IgG antibody (Jackson Immuno Research, West Grove, PA) and avidin-FITC (EY Laboratories, San Mateo, CA) were obtained through Cedarlane Laboratories (Burlington, ON). The In Situ Cell Death Detection Kit, Fluorescein was purchased from Roche (Laval, QC)

\section{Animals}

All animal procedures followed the guidelines established by the Canadian Council of Animal Care and approved by 


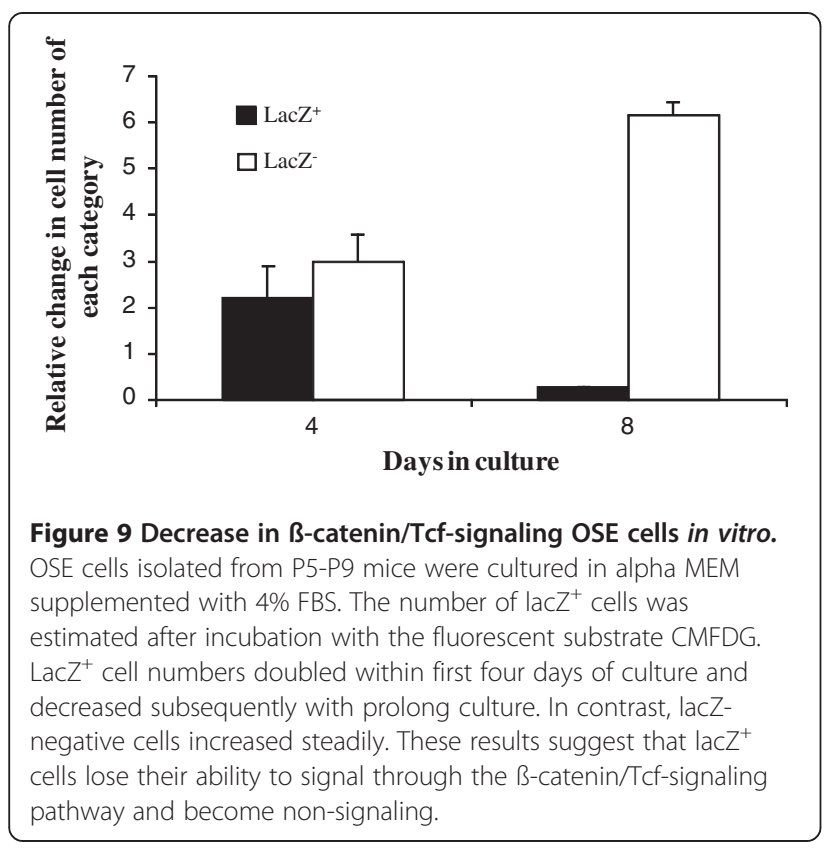

the Animal Care Committee of the Royal Victoria Hospital, McGill University. CD1 mice bearing the $\beta$-catenin/Tcf-responsive lacZ reporter gene (TopGal mice) have been described [28]. Dr. Daniel Dufort (Department of Obstetrics and Gynecology, McGill University, Montreal, Canada) provided us with female and male CD1 mice, homozygous for the transgene, for colony establishment. Dr Makoto C. Nagano (Department of Obstetrics and Gynecology, McGill University, Montreal, Canada) provided us with wild type CD1 mice. Female mice were examined daily for vaginal plugs. The day of plug detection was considered day 0.5 of gestation and the day after birth designated postnatal day 1 (P1). Gonads were isolated from a minimum of three mice for analysis and all experiments replicated at least thrice.

\section{Tissue processing}

Mice were sacrificed by cervical dislocation. Gonads were isolated, washed in phosphate buffered saline (PBS; $137 \mathrm{mM} \mathrm{NaCl}, 2.7 \mathrm{mM} \mathrm{KCl}, 8 \mathrm{mM} \mathrm{Na} \mathrm{HPO}_{4}, 2 \mathrm{mM}$ $\mathrm{KH}_{2} \mathrm{PO}_{4}, \mathrm{pH}$ 7.4) and fixed for 5-15 min in freshly prepared 4\% paraformaldehyde (PFA) in PBS. After rinsing in wash buffer (PBS containing $2 \mathrm{mM} \mathrm{MgCl}_{2}, 0.1 \%$ Triton, $0.05 \%$ sodium deoxycholate), gonads were stained in the dark overnight at $37^{\circ} \mathrm{C}$ in wash buffer supplemented with $1 \mathrm{mg} / \mathrm{ml} \mathrm{X}$-gal, $0.04 \% \mathrm{~N}$, N-dimethyl formamide, $5 \mathrm{mM}$ potassium ferricyanide and $5 \mathrm{mM}$ potassium ferrocyanide to disclose $\beta$-galactosidase activity [66]. Following staining, gonads were washed in PBS and photographed or processed for histology.

Table 2 Expression of wnts and frizzleds in OSE cells harvested from different animal ages and primer sequences for RT-PCR analysis

\begin{tabular}{|c|c|c|c|c|c|c|}
\hline Gene & P5 & P10 & P21 & Adult ( $>6$ wks old) & Forward primer & Reverse primer \\
\hline$\overline{W n t 2}$ & + & + & + & + & CGACTGGGGTGGCTGCAGTG & $\overline{\text { AGGGAGCCTGCCTCTCGGTC }}$ \\
\hline Wnt2b & + & + & + & + & CATGATCAACGAGGGGACTT & CAGCCTTGTCCAAGACACAGT \\
\hline Wnt3a & - & - & - & - & CAAGCCGGCGATGGCTCCTC & ACTCCCGGGTGGCTITGTCCA \\
\hline Wnt4 & + & + & + & + & GGCGTAGCCTTCTCACAGTC & GCCGTCAATGGCTTTAGATG \\
\hline Wnt5a & + & + & + & + & AGGAGTTCGTGGACGCTAGA & GTCCATCCCCTCTGAGGTCT \\
\hline Wnt7a & - & - & - & - & CTGGCGGGATCAGCACAGCC & CAGCCTCCCGACTCCCCACT \\
\hline Wnt8a & - & - & - & - & TCGTGGACAGTTGGAGAAA & GTTGCGGTTGCAGTAGTCAG \\
\hline Wnt11 & + & + & + & + & CGTGTGCTATGGCATCAAGT & CGTGTGCTATGGCATCAAGT \\
\hline GAPDH & + & + & + & + & ACAACTTTGGCATTGTGGAA & GATGCAGGGATGATGTTCTG \\
\hline Fzd 1 & + & + & + & + & CCGAGCTCAAGTTCTTCCTG & GGGAACTTCTCGCACTTGAG \\
\hline Fzd 2 & + & + & + & + & TTCTTCACGGTCACCACCTA & AATGTAGGCCACTGACACCA \\
\hline Fzd 3 & + & + & + & + & CCAGGAACCTGACTTTGCTC & GACACTCCCTGCTITGCTTC \\
\hline Fzd 4 & + & + & + & + & TGCAGTTCTTCCTITGTTCG & TCTCAGGACTGGTTCACAGC \\
\hline Fzd 5 & + & + & + & + & GACGCCGAGGTTCTGTGTAT & TCGTTCCATGTCAATGAGGA \\
\hline Fzd 6 & + & + & + & + & CACAAATCATGGCACCTCTG & GGTTGGTTCTGGAGAACTGG \\
\hline Fzd 7 & + & + & + & + & GCCTACAACCAGACCATCCT & GCACACGGGTGCGTACATAG \\
\hline Fzd 8 & - & - & - & - & CCTTCGCCACTGTCTCTACC & ACGTGAGCGACAGGATTACC \\
\hline Fzd 9 & + & + & + & + & CCAGTACGTGGAGAAGAGTCG & GAAGGTGAACACGGTGAAGG \\
\hline Fzd 10 & + & + & + & + & GAGCACGGGCTGTACCTTAG & ATGAAGGAAGTGCCGATGAC \\
\hline
\end{tabular}

+/- indicates presences or absences of RT-PCR product. 

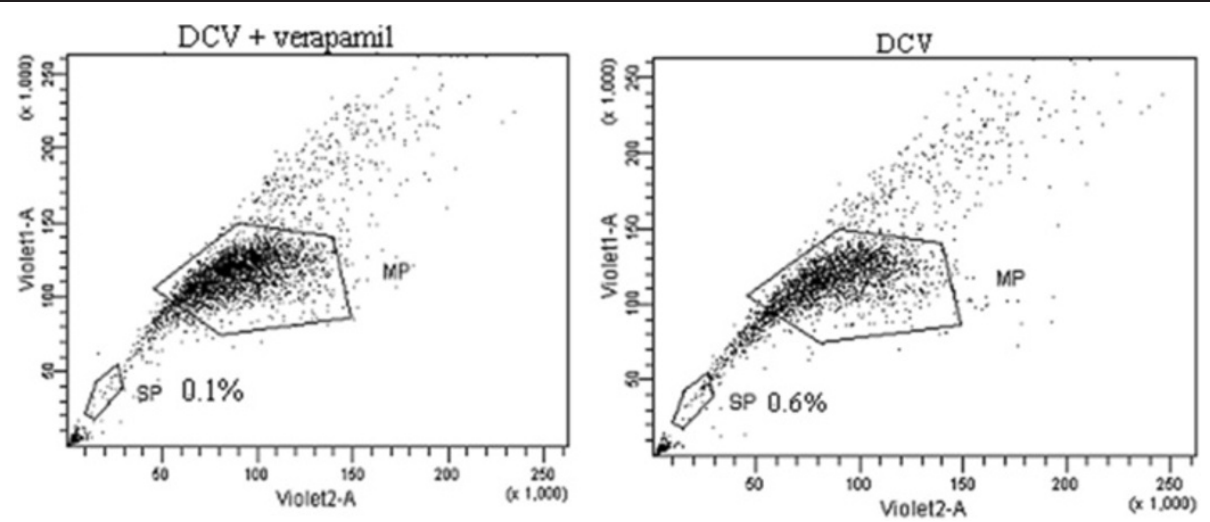

Figure 10 OSE cells show a side population (SP). Dye cycle violet (DCV) SP analysis of OSE cells. OSE cells harvested from prepubertal mice were stained with DCV in the presence or absence of the ABCG2 inhibitor verapamil. Addition of verapamil resulted in reduction in SP. The ratio of SP cells to total viable cells is indicated as a percentage in the scatter plot. Boxed cells (labeled MP) represent the main population.

\section{Histology}

X-gal-stained ovaries were post-fixed in 4\% PFA overnight at room temperature (RT), rinsed in PBS, and embedded in paraffin. Sections were cut $6 \mu \mathrm{m}$ thick, mounted on glass slides and counterstained with hematoxylin and eosin. In studies where OSE cell numbers were estimated,

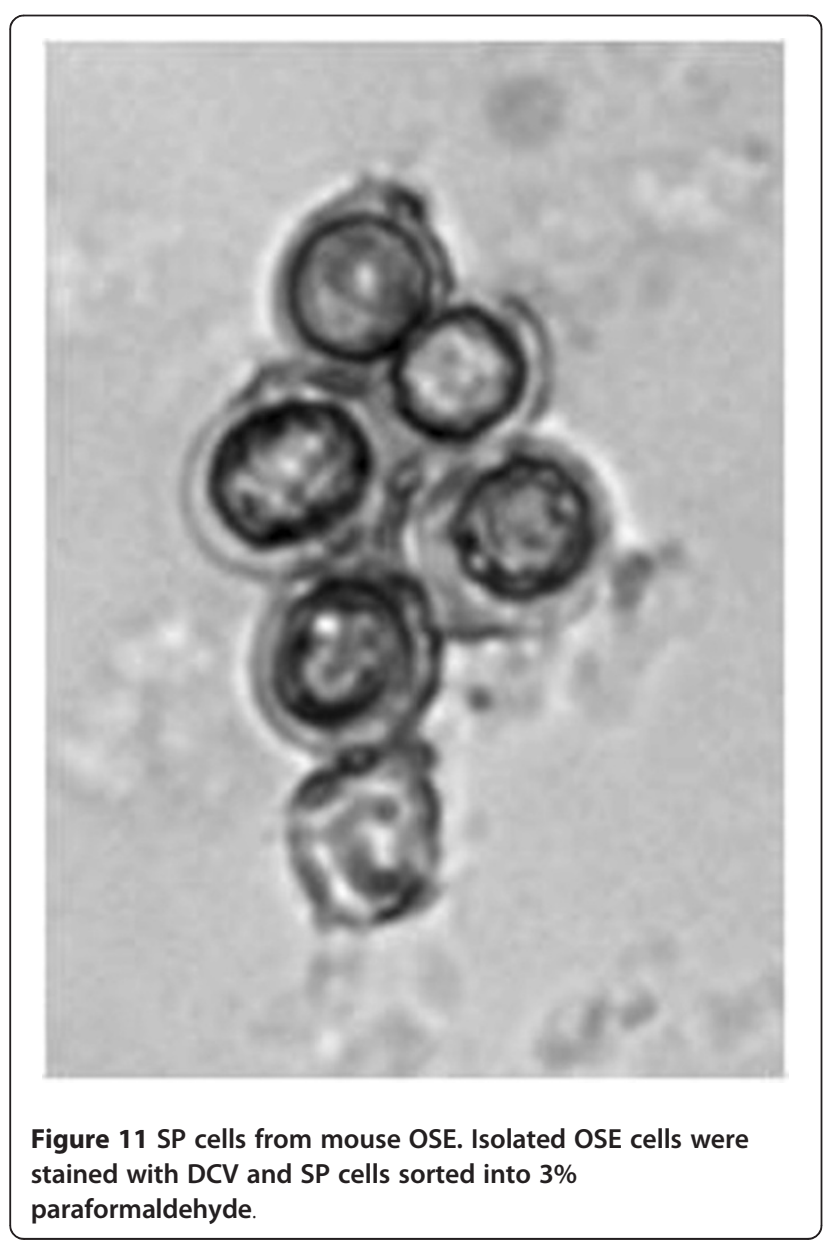

sections were stained with periodic acid Schiff (PAS) to define the basement membrane and counterstained with Hoechst 33342 to identify cell nuclei. The total number of OSE cells was estimated by applying the nucleator and fractionator principle described by Gundersen [67]. Only cells with large visible nuclei were counted. Every fourth ovary section was evaluated and an estimate of the total number of OSE cells per ovary determined by multiplying the cell counts by four. LacZ-positive OSE cells were determined by evaluating every section of the ovary since these cells were not uniformly distributed.

\section{OSE labeling and isolation}

OSE cells were isolated as follows: ovaries (2 ovaries/ $0.5 \mathrm{ml}$ DMEM) were placed in a $1.5 \mathrm{ml}$ capped tube and incubated for $60 \mathrm{~min}$ at $37^{\circ} \mathrm{C}$ in DMEM containing $1 \mathrm{mg} / \mathrm{ml}$ Type IV collagenase, $1 \mathrm{mg} / \mathrm{ml}$ deoxyribonuclease I, and $0.53 \mathrm{mM}$ EDTA. Ovaries were agitated every $10 \mathrm{~min}$ by swirling the tube for a few seconds. Released cells were transferred to a fresh tube. The ovaries were rinsed in fresh DMEM and additional released cells combined with the previously isolated cell suspension. The cell suspension was vortexed and cells pelleted by centrifugation at $500 \mathrm{~g}$ for $5 \mathrm{~min}$. The cell pellet was washed with PBS and resuspended in PBS.

We needed to confirm that our isolation procedure yielded primarily OSE cells with minimal contamination by other ovarian cells. Additionally, we wanted to assess the efficiency of the OSE isolation procedure. This was accomplished by labeling OSE cells in situ. We took advantage of a water-soluble and membrane impermeable biotinylation reagent (Sulfo NHS-biotin) that reacts chemically with exposed amine groups of cell surface proteins. Intact ovaries were incubated in $1 \mathrm{mg} / \mathrm{ml}$ Sulfo NHS-biotin in PBS for $1 \mathrm{~min}$ at $4^{\circ} \mathrm{C}$. The reaction was quenched by incubating the ovary in ice-cold PBS 
Table 3 Percentage of side population (SP) cells relative to total viable OSE cells and $\beta$-catenin/Tcf-signaling cells as a fraction of total lacZ ${ }^{+}$OSE cells in SP and main population (MP)

\begin{tabular}{cccc}
\hline Animal age (days) & $\begin{array}{c}\% \text { SP/total } \\
\text { viable cells }\end{array}$ & $\begin{array}{c}\% \text { lacZ cells } \\
\text { in SP }\end{array}$ & $\begin{array}{c}\%_{\text {lacZ }}^{+} \text {cells in } \\
\text { MP }\end{array}$ \\
\hline 24 & 0.8 & 25 & 75 \\
26 & 0.6 & 20 & 80 \\
35 & 0.5 & 27 & 73 \\
\hline
\end{tabular}

containing $0.1 \mathrm{M}$ glycine for $1 \mathrm{~min}$. Selective labeling of OSE cells was confirmed by preparing sections of NHSbiotin-labeled ovaries followed by incubation with avidin-conjugated FITC (1:200 in PBS). Sections of enzymatically-treated ovaries were also examined for the extent of OSE removed by avidin-FITC staining.

\section{Immunofluorescence}

Cytokeratin 8 (CK8) staining was performed on paraffinembedded sections and isolated OSE cells. Six $\mu \mathrm{m}$ thick paraffin tissue sections were deparaffinized with xylene and rehydrated in graded ethanol. Antigen retrieval was performed by boiling the sections in $10 \mathrm{mM}$ sodium citrate buffer, $\mathrm{pH} 6.0$, for $25 \mathrm{~min}$. After rinsing in PBST (PBS $+0.5 \%$ Tween), nonspecific binding was blocked for 30 min in blocking solution (5\% BSA in PBST). Sections were incubated with primary antibody (TROMA-1) in blocking solution at $4^{\circ} \mathrm{C}$ overnight. The primary antibody was omitted for negative control slides. Slides were subsequently rinsed in PBST, incubated with Cy3-labeled goat anti-mouse antibody diluted 1:200 in blocking solution for $60 \mathrm{~min}$ in the dark, counterstained with DAPI, and mounted in mowiol.

Isolated OSE cells $(50,000$ cells $/ \mathrm{ml})$ were cytospun onto slides, fixed in 4\% PFA for $5 \mathrm{~min}$, and processed for CK8 staining as described above. Cell counts were made in five microscopic fields and approximately 100 cells were counted per field.

\section{Fluorescence-activated cell sorting (FACS) analysis}

LacZ expression in isolated OSE cells was detected using the DetectaGene Green CMFDG LacZ gene expression kit as outlined by the supplier (Invitrogen). OSE cells were washed in PBS and incubated with pre-warmed $0.1 \mathrm{M}$ CMFDG in PBS at $37^{\circ} \mathrm{C}$ for $15 \mathrm{~min}$. PI was added to label dead cells and FACS analysis performed on a Becton-Dickinson FACScan. Wild type CD1 OSE cells were used as controls. Dual parametric analysis of forward versus side scatter was the primary gate for identification of cells in the appropriate size range and to eliminate cell debris.
TUNEL (terminal deoxynucleotidyl transferase dUTP nick end labeling) staining

Six $\mu \mathrm{m}$ thick paraffin-embedded lacZ-stained ovary sections from each age under investigation were examined for the presence of fragmented DNA indicating apoptosis using the In Situ Cell Death Detection Kit, Fluorescein, according to the manufacturer's instructions (Roche). Sections were counterstained with PI to label cell nuclei and mounted in mowiol.

\section{BrdU labeling}

A solution of $1 \mathrm{mg} 5^{\prime}$-bromo-2'-deoxyuridine (BrdU)/ $100 \mu \mathrm{l}$ PBS was freshly prepared and filter sterilized $(0.45 \mu \mathrm{m}$ filter). Mice received BrdU by injection (i.p.) of $100 \mu \mathrm{l}$ of sterile preparation. Ovaries were collected $48 \mathrm{hrs}$ later and stained for $\mathrm{X}$-gal, post fixed in $4 \%$ PFA overnight and embedded in paraffin. To detect proliferating cells, $6 \mu \mathrm{m}$ thick paraffin sections were analyzed using a monoclonal mouse antibody (DSHB) specific for BrdU. Sections were dewaxed, washed in PBST (PBS + $0.5 \%$ Tween 20) and incubated with $2 \mathrm{~N} \mathrm{HCl}$ at RT for $1 \mathrm{hr}$. Subsequently, slides were rinsed $3 \times 5$ mins in PBST and blocked in a blocking solution (3\% BSA in PBST) for 30 mins. Sections were then incubated with antiBrdU antibody diluted 1:100 in blocking solution at $4^{\circ} \mathrm{C}$ overnight. Following primary antibody incubation, slides were rinsed $3 \times 5$ mins in PBST, incubated with an FITClabeled goat anti-mouse secondary antibody diluted $1: 100$ in blocking solution overnight at $4^{\circ} \mathrm{C}$, counterstained with DAPI, and mounted in mowiol.

\section{RT-PCR}

Total RNA was isolated from FACS-sorted OSE cells using the miRNeasy Mini kit (Qiagen, Toronto, ON) and incorporating on-column RNase-free DNase digestion. Quantity and quality of mRNA samples were assured by analysis with the Thermo Scientific NanoDrop 2000 (Thermo Scientific, Wilmington, DE). To survey the expression of wht signaling components, total RNA (100 ng) was reverse transcribed using M-MLV reverse transcriptase (Invitrogen). Polymerase chain reactions (PCRs) were conducted as described previously [68]. Wnts for RT-PCR analysis were selected based on previous studies $[15,19]$. A PCR reaction for a known housekeeping gene, GAPDH, was generated as an internal control. The annealing temperature for each primer pair was optimized using positive control tissues to generate single bands corresponding to correct product sizes. Information regarding positive control tissue in which the genes of interest are expressed was obtained from: (i) Mouse Genome Database (MGD) (http://www.informatics.jax.org 09/2009), RT-PCR database and included brain (for wnt2, wnt 4 , wnt $7 \mathrm{a}$, wnt $8 \mathrm{a}$, wnt 11 ), eye (wnt5a), testis (wnt3a); and (ii) a previous study [69]. 
The RT-PCR protocol was performed on two separate RNA preparations. For each sample, a RT-minus control was included to provide for a negative control for subsequent PCR. All minus RT controls were negative. PCR products were visualized on a UV transilluminator after electrophoresis on a 1\% agarose gel in TAE buffer (40 mM Tris, $1 \mathrm{mM}$ EDTA and $20 \mathrm{mM}$ acetic acid) and SafeView nucleic acid staining.

\section{Side population (SP) analysis}

OSE cells were labeled with DyeCycle Violet (DCV) according to a modified protocol [70]. Briefly, OSE cells were suspended in the appropriate medium (DMEM containing $2 \%$ FBS and $2 \mathrm{mM}$ HEPES) at $1 \times 10^{6}$ cells/ $\mathrm{ml}$. Before DCV incubation, cells were pre-incubated for 15 mins with or without $50 \mu \mathrm{M}$ verapamil. DCV was added to the cell suspension at a final concentration of $5 \mu \mathrm{M}$ and the mixture incubated for 30 minutes at $37^{\circ} \mathrm{C}$ in the dark. Propidium iodide was added to a final concentration of $1 \mu \mathrm{g} / \mathrm{mL}$ to identify dead cells. FACS analysis and sorting were performed on a dual laser flow cytometer (Becton Dickinson). The SP was defined as described previously [71].

\section{Cell culture}

OSE cells isolated from postnatal day 5 (P5) to P9 mice were grown in MEM alpha [72] supplemented with $4 \%$ FBS and $20 \mathrm{U} / \mathrm{ml}$ PenStrep at a density of $\sim 3000$ cells/ well in 96-well plates. The cells were grown in a humidified incubator at $37^{\circ} \mathrm{C}$ and $5 \% \mathrm{CO}_{2}$.

\section{Statistical analysis}

Data were analyzed using SYSTAT 10.2 statistical software (SYSTAT Software, Richmond, CA). Analysis of variance (ANOVA) was used with Tukey's test in the post hoc analysis for cell counts to ascertain group mean differences. Data for the percentage of lacZ-positive OSE cells obtained following CMFDG labeling was subjected to ANOVA after arcsine transformation [73]. Data are presented as mean \pm standard error of the mean. $\mathrm{P} \leq 0.05$ was considered significant.

\section{Authors' contributions}

RF designed research; UM performed research and analyzed data; RF and UM wrote the paper. Both authors read and approved the final manuscript.

\section{Acknowledgements}

We are grateful to Ken McDonald (Life Science Complex, McGill University) for his technical assistance in flow cytometry. The authors thank Makoto C. Nagano for discussions. This study was funded by grants from the Canadian Institutes of Health Research (CIHR) and the Natural Sciences and Engineering Research Council of Canada (NSERC).

\section{Author details}

${ }^{1}$ Departments of Experimental Medicine, McGill University, Montreal, QC, Canada. ${ }^{2}$ Obstetrics and Gynecology, McGill University, Montreal, QC, Canada. ${ }^{3}$ Physiology, McGill University, Montreal, QC, Canada. ${ }^{4}$ Department of
Obstetrics and Gynecology, F344 Royal Victoria Hospital, 687 Pine Avenue West, Montreal H3A 1A1QC, Canada.

Received: 13 September 2011 Accepted: 28 March 2012

Published: 8 June 2012

\section{References}

1. Miller JR: Genome Biol 2002, 3:REVIEWS3001.

2. Behrens J, von Kries JP, Kuhl M, Bruhn L, Wedlich D, Grosschedl R, Birchmeier W: Functional interaction of beta-catenin with the transcription factor LEF-1. Nature 1996, 382:638-642.

3. Wodarz A, Nusse R: Mechanisms of Wnt signaling in development. Annu Rev Cell Dev Biol 1998, 14:59-88.

4. Logan CY, Nusse R: The Wnt signaling pathway in development and disease. Annu Rev Cell Dev Biol 2004, 20:781-810.

5. Cadigan KM: Wnt-beta-catenin signaling. Curr Biol 2008, 18:R943-R947.

6. Vainio S, Heikkila M, Kispert A, Chin N, McMahon AP: Female development in mammals is regulated by Wnt-4 signalling. Nature 1999, 397:405-409.

7. Jeays-Ward K, Hoyle C, Brennan J, Dandonneau M, Alldus G, Capel B, Swain A: Endothelial and steroidogenic cell migration are regulated by WNT4 in the developing mammalian gonad. Development 2003, 130:3663-3670.

8. Heikkila M, Peltoketo $H$, Leppaluoto J, Ilves $M$, Vuolteenaho $O$, Vainio S: Wnt-4 deficiency alters mouse adrenal cortex function, reducing aldosterone production. Endocrinology 2002, 143:4358-4365.

9. Cederroth CR, Pitetti JL, Papaioannou MD, Nef S: Genetic programs that regulate testicular and ovarian development. Mol Cell Endocrinol 2007, 265-266:3-9.

10. Parma P, Radi O, Vidal V, Chaboissier MC, Dellambra E, Valentini S, Guerra L, Schedl A, Camerino G: R-spondin1 is essential in sex determination, skin differentiation and malignancy. Nat Genet 2006, 38:1304-1309.

11. Tomizuka K, Horikoshi $K$, Kitada R, Sugawara $Y$, Iba $Y$, Kojima A, Yoshitome A Yamawaki K, Amagai M, Inoue A, Oshima T, Kakitani M: R-spondin1 plays an essential role in ovarian development through positively regulating Wnt-4 signaling. Hum Mol Genet 2008, 17:1278-1291.

12. Kazanskaya O, Glinka A, Barrantes ID, Stannek P, Niehrs C, Wu W: Rspondin2 is a secreted activator of Wnt/beta-catenin signaling and is required for Xenopus myogenesis. Dev Cell 2004, 7:525-534.

13. Ottolenghi C, Pelosi E, Tran J, Colombino M, Douglass E, Nedorezov T, Cao A, Forabosco A, Schlessinger D: Loss of Wnt4 and Foxl2 leads to femaleto-male sex reversal extending to germ cells. Hum Mol Gen 2007, 16:2795-2804

14. Yao HHC, Matzuk MM, Jorgez CJ, Menke DB, Page DC, Swain A, Capel B: Follistatin operates downstream of Wnt4 in mammalian ovary organogenesis. Dev Dyn 2004, 230:210-215.

15. Hsieh M, Johnson MA, Greenberg NM, Richards JS: Regulated expression of Wnts and frizzleds at specific stages of follicular development in the rodent ovary. Endocrinology 2002, 143:898-908.

16. Hsieh M, Boerboom D, Shimada M, LO Y, Parlow AF, Luhmann UFO, Berger W, Richards JS: Mice null for Frizzled4 (Fzd4(-/-)) are infertile and exhibit impaired corpora lutea formation and function. Biol Reprod 2005, 73:1135-1146.

17. Hsieh M, Mulders SM, Friis RR, Dharmarajan A, Richards JS: Expression and localization of secreted frizzled-related protein-4 in the rodent ovary: Evidence for selective up-regulation in luteinized granulosa cells. Endocrinology 2003, 144:4597-4606.

18. Ricken A, Lochhead P, Kontogiannea M, Farookhi R: Wnt signaling in the ovary: identification and compartmentalized expression of wnt-2, wnt-2b, and frizzled-4 mRNAs. Endocrinology 2002, 143:2741-2749.

19. Harwood BN, Cross SK, Radford EE, Haac BE, De Vries WN: Members of the WNT signaling pathways are widely expressed in mouse ovaries, oocytes, and cleavage stage embryos. Dev Dyn 2008, 237:1099-1111.

20. Kimura T, Nakamura T, Murayama K, Umehara H, Yamano N, Watanabe S, Taketo MM, Nakano T: The stabilization of beta-catenin leads to impaired primordial germ cell development via aberrant cell cycle progression. Dev Biol 2006, 300:545-553.

21. Lyons JP, Mueller UW, Ji H, Everett C, Fang X, Hsieh JC, Barth AM, McCrea PD: Wnt-4 activates the canonical beta-catenin-mediated Wnt pathway and binds Frizzled-6 CRD: functional implications of Wnt/ beta-catenin activity in kidney epithelial cells. Exp Cell Res 2004, 298:369-387. 
22. Katoh M, Kirikoshi $H$, Terasaki $H$, Shiokawa K: WNT2B2 mRNA, up-regulated in primary gastric cancer, is a positive regulator of the WNT-beta-catenin-TCF signaling pathway. Biochem Biophy Res Commun 2001, 289:1093-1098.

23. Byskov AG: Differentiation of mammalian embryonic gonad. Physio/ Rev 1986, 66:71-117.

24. Naora $\mathrm{H}$ : The heterogeneity of epithelial ovarian cancers: reconciling old and new paradigms. Expert Rev Mol Med 2007, 9:1-12.

25. Murdoch WJ: Ovarian Surface Epithelium during Ovulatory and Anovulatory Ovine Estrous Cycles. Anat Rec 1994, 240:322-326.

26. Szotek PP, Chang HL, Brennand K, Fujino A, Pieretti-Vanmarcke R, Lo Celso C, Dombkowski D, Preffer F, Cohen KS, Teixeira J, Donahoe PK: Normal ovarian surface epithelial label-retaining cells exhibit stem/progenitor cell characteristics. Proc Natl Acad Sci U S A 2008, 105:12469-12473.

27. Gatcliffe TA, Monk BJ, Planutis K, Holcombe RF: Wnt signaling in ovarian tumorigenesis. Int J Gynecol Cancer 2008, 18:954-962.

28. Mohamed OA, Clarke HJ, Dufort D: beta-catenin signaling marks the prospective site of primitive streak formation in the mouse embryo. Dev Dyn 2004, 231:416-424.

29. Goodell MA, Brose K, Paradis G, Conner AS, Mulligan RC: Isolation and functional properties of murine hematopoietic stem cells that are replicating in vivo. J Exp Med 1996, 183:1797-1806.

30. Kurman RJ, Shih le M: The origin and pathogenesis of epithelial ovarian cancer: a proposed unifying theory. Am J Surg Pathol 2010, 34:433-443.

31. Guigon JC, Magre S: Contribution of germ cells to the differentiation and maturation of the ovary: insights from models of germ cell depletion. Biol Reprod 2006, 74:450-458.

32. Karl J, Capel B: Sertoli cells of the mouse testis originate from the coelomic epithelium. Dev Biol 1998, 203:323-333.

33. Aravindakshan J, Chen X, Sairam MR: Differential expression of claudin family proteins in mouse ovarian serous papillary epithelial adenoma in aging FSH receptor-deficient mutants. Neoplasia 2006, 8:984-994.

34. Mao CD, Hoang P, DiCorleto PE: Lithium inhibits cell cycle progression and induces stabilization of p53 in bovine aortic endothelial cells. J Biol Chem 2001, 276:26180-26188.

35. Pang KM, Evans M, Hay ED: Overexpression of beta-catenin induces apoptosis independent of its transactivation function with LEF-1 or the involvement of major G1 cell cycle regulators. Mol Biol Cell 2000, 11:3509-3523.

36. Guo N, Hawkins C, Nathans J: Frizzled6 controls hair patterning in mice. Proc Natl Acad Sci U S A 2004, 101:9277-9281.

37. Fröjmark AS, Schuster J, Sobol M, Entesarian M, Kilander MB, Gabrikova D, Nawaz S, Baig SM, Schulte G, Klar J, Dahl N: Mutations in Frizzled 6 cause isolated autosomal-recessive nail dysplasia. Am J Hum Genet 2011, 88:852-860.

38. van Noort M, Clevers H: TCF transcription factors, mediators of Wntsignaling in development and cancer. Dev Biol 2002, 244:1-8.

39. Kriedberg JA, Sariola H, Loring JM, Maeda M, Pelletier J, Housman D, Jaenisch R: Wt-1 is required for early kidney development. Cell 1993, 74:679-691

40. Miyamoto N, Yoshida M, Kurani S, Matsuo I, Aizawa S: Defects of urogenital development in mice lacking Emx2. Development 1997, 124:1653-1664.

41. Liu CF, Bingham N, Parker K, Yao HHC: Sex-specific roles of beta-catenin in mouse gonadal development. Hum Mol Gen 2009, 18:405-417.

42. Greenfield A: Genes, cells and organs: recent developments in the molecular genetics of mammalian sex determination. Mamm Genome 1998, 9:683-687.

43. Capel B: The battle of the sexes. Mech Dev 2000, 92:89-103.

44. McLaren A: Germ and somatic cell lineages in the developing gonad. Mol Cell Endocrinol 2000, 163:3-9.

45. Menke DB, Koubova J, Page DC: Sexual differentiation of germ cells in XX mouse gonads occurs in an anterior-to-posterior wave. Dev Biol 2003, 262:303-312.

46. Menke DB, Page DC: Sexually dimorphic gene expression in the developing mouse gonad. Gene Expr Patterns 2002, 2:359-367.

47. Sakata S, Sakamaki K, Watanabe K, Nakamuru N, Toyokuni S, Nishimune Y, Mori C, Yonehara S: Involvement of death receptor Fas in germ cell degeneration in gonads of kit-deficient Wv/Wv mutant mice. Cell Death Differ 2003, 10:676-686.

48. Bernard P, Sim H, Knower K, Vilain E, Harley V: Human SRY inhibits beta-catenin-mediated transcription. Int J Biochem Cell Biol 2008, 40:2889-2900.
49. Albrecht KH, Eicher EM: Evidence That Sry Is Expressed in Pre-Sertoli Cells and Sertoli and Granulosa Cells Have a Common Precursor. Dev Biol 2001, 240:92-107.

50. Tevosian SG, Albrecht KH, Crispino JD, Fugiwara Y, Eicher EM, Orkin SH: Gonadal differentiation, sex determination and normal Sry expression in mice require direct interaction between transcription partners GATA4 and FOG2. Development 2002, 129:4627-4634.

51. Greco TL, Payne AH: Ontogeny of expression of the genes for steroidogenic enzymes $\mathrm{P} 450$ side-chain cleavage, 3 betahydroxysteroid dehydrogenase, P450 17 alpha-hydroxylase/C17-20 lyase, and P450 aromatase in fetal mouse gonads. Endocrinology 1994, 135:262-268.

52. Nicosia SV, Johnson JH, Streibel EJ: Isolation and Ultrastructure of Rabbit Ovarian Mesothelium (Surface Epithelium). Int J Gynecol Pathol 1984, 3(4):348-360.

53. Symonds DA, Dragana T, Kimberly PM, Jodi AF: Methoxychlor induces proliferation of the mouse ovarian surface epithelium. Toxicol Sci 2005 83(2):355-362

54. Clark-Knowles KV, Garson K, Jonkers J, Vanderhyden BC: Conditional inactivation of Brca1 in the mouse ovarian surface epithelium results in an increase in preneoplastic changes. Exp Cell Res 2007, 313(1):133-145.

55. Quinn BA, Drake T, Hua X, Baxter-Jones K, Litwin S, Ellenson LH, Connolly DC: Induction of ovarian leiomyosarcomas in mice by conditional inactivation of Brca1 and p53. PLoS One 2009, 4(12):e8404

56. Olmeda D, Castel S, Vilaro S, Cano A: Beta-catenin regulation during the cell cycle: implications in G2/M and apoptosis. Mol Biol Cell 2003, 2844-2860.

57. Llius F, Pedone E, Pepe S, Cosma MP: The Wnt/beta-catenin signaling pathway tips the balance between apoptosis and reprograming of cell fusion hybrids. Stem Cells 2010, 28:1940-1949.

58. Dharma SJ, Modi DN, Nandedkar TD: Gene expression profiling during early folliculogenesis in the mouse ovary. Fertil Steril 2009, 91:2025-2036.

59. Parr BA, McMahon AP: Sexually dimorphic development of the mammalian reproductive tract requires Wnt-7a. Nature 1998, 395:707-710.

60. Wang HX, Li TY, Kidder GM: WNT2 regulates DNA synthesis in mouse granulosa cells through beta-catenin. Biol Reprod 2010, 82:865-875.

61. Bowen NJ, Walker LD, Matyunina LV, Logani S, Totten KA, Benigno BB, McDonald JF: Gene expression profiling supports the hypothesis that human ovarian surface epithelia are multipotent and capable of serving as ovarian cancer initiating cells. BMC Med Genomics 2009, 2:71.

62. Virant-Klun I, Skutella T, Stimpfel M, Sinkovec J: Ovarian surface epithelium in patients with severe ovarian infertility: a potential source of cells expressing markers of pluripotent/multipotent stem cells. J Biomed Biotech 2011, 381928.

63. Vermeulen L, De Sousa EMF, van der Heijden M, Cameron K, de Jong JH, Borovski T, Tuynman JB, Todaro M, Merz C, Rodermond H, Sprick MR, Kemper K, Richel DJ, Stassi G, Medema JP: Wnt activity defines colon cancer stem cells and is regulated by the microenvironment. Nat Cell Biol 2010, 12:468-476.

64. Fevr T, Robine S, Louvard D, Huelsken J: Wnt/beta-Catenin is essential for intestinal Homeostasis and maintenance of intestinal stem cells. Mol Cell Biol 2007, 27:7551-7559.

65. Rossi DJ, Jamieson CH, Weissman IL: Stems cells and the pathways to aging and cancer. Cell 2008, 132:681-696.

66. Iglesias DM, Hueber PA, Chu L, Campbell R, Patenaude AM, Dziarmaga AJ, Quinlan J, Mohamed O, Dufort D, Goodyer PR: Canonical WNT signaling during kidney development. Am J Physiol Renal Physiol 2007, 293:F494-F500.

67. Gundersen HJ: The smooth fractionator. J Microsc 2002, 207:191-210.

68. van den Berg A, van der Leij J, Poppema S: Serial analysis of gene expression: rapid RT-PCR analysis of unknown SAGE tags. Nucl Acids Res 1999, 27:e17.

69. Zeng G, Awan F, Otruba W, Muller P, Apte U, Tan X, Gandhi C, Demetris AJ, Monga SP: Wnt'er in liver: expression of Wnt and frizzled genes in mouse. Hepatology, 2007. 45(1):195-204.

70. Telford WG: Stem cell side population analysis and sorting using DyeCycle violet. Curr Protoc Cytom 2010, Chapter 9:Unit9 30.

71. Goodell MA, McKinney-Freeman S, Camargo FD: Isolation and characterization of side population cells. Methods Mol Biol 2005, 290:343-352. 
72. Walsh RJ, Matsuzaki S, Reinot T, Hayes JM, Kalli KR, Hartmann LC, Small GJ: Single-cell nonphotochemical hole burning of ovarian surface epithelial carcinoma and normal cells. Proc Natl Acad Sci U S A 2003, 100:1685-1689.

73. McDonald JH: Handbook of Biological Statistics. 2nd edition. Baltimore, Maryland: Sparky House Publishing; 2009.

doi:10.1186/1471-213X-12-17

Cite this article as: Usongo and Farookhi: $\beta$-catenin/Tcf-signaling appears to establish the murine ovarian surface epithelium (OSE) and remains active in selected postnatal OSE cells. BMC Developmental

Biology 2012 12:17.

\section{Submit your next manuscript to BioMed Central and take full advantage of:}

- Convenient online submission

- Thorough peer review

- No space constraints or color figure charges

- Immediate publication on acceptance

- Inclusion in PubMed, CAS, Scopus and Google Scholar

- Research which is freely available for redistribution 